Puthut Ardianto

earned his undergraduate and master's degree from the English Language Teaching Department at Universitas Sarjanawiyata Tamansiswa, Yogyakarta. He has been teaching English since 2006 across a range of different age levels and proficiencies. His research interests are creative writing (folktales), learning strategies (speaking), and linguistics.

\title{
Communication Strategies in English Conversations
}

\section{$16-25$}

\begin{abstract}
This research aims to reveal communication strategies used by students of the English Education Department of a university in Indonesia in English conversations and to find out the moments when the strategies were used. This research employed an interlanguage analysis. There were four participants who were asked to converse under a certain picture and was audio-recorded, transcribed, coded, and analysed. The findings show that the participants employed thirteen strategies when they were having English conversations.

Keywords: communication strategies, English conversations
\end{abstract}

\section{INTRODUCTION}

People are not born with the competency of understanding everything that happens in the world immediately. They use a process to understand how to survive their life. For example, when non English speakers involve in an English conversation for the first time, they might not be able to contribute significantly in the conversation. This might be a matter of employing strategies in speaking English. As what mentioned by Muho and Kurani (2011), all foreign/second language learners use strategies either consciously or unconsciously when processing new information and performing tasks in language classrooms. These strategies are expected to help learners keep conversing in English.

Some foreign/second language learners use communication strategies when they find problems conveying their ideas and thoughts in the target language. This happens when the learners cannot select or use appropriate words, idioms, structures, phrases, or the combinations of those language features. These problems are likely caused by their lack of communication competence. By employing the strategies, learners are expected to reduce or remove difficulties in transferring their thoughts and ideas to others (Lam, 2006 cited in Ugla, 2013). 
This phenomenon also occured at the English Education Department where the researcher frequently converses with students in English. In most occasions, although they face some problems when being involved in English conversations, these students do not only keep silent; instead, they force themselves to engange in the conversations by using a variety of strategies. Yule and Tarone (1991) as cited in Spromberg (2011) stated if interlocutors are at the phase where they do not understand one another, they might be expected to "work out negotiate some form of common ground before the interaction can continue" (p. 162). To deal with problems between the interlocutors, understanding the message conveyed by using communication strategies should be applied. Therefore, this study focuses on investigating the communication strategies used by English students in English conversations. The other objective of the study is to see in which situations these strategies are used by the learners. In fact, in employing the strategies, interlocutors will neither use the native language nor the target language systematically. In other words, it is called interlanguage.

\section{INTERLANGUAGE}

According to Richards, Platt, and Candlin (1992), interlanguage is the type of language produced by foreign/second language students who are in the process of learning a language. In other words, interlanguage is the students' current version of the language they are learning, e.g., an Indonesian English learner might say "David not study" instead of "David does not study". This might happen since Indonesian language does not have the same negation form as in English (auxiliary + NOT). Another example is given by Tarone (2006) who said that when a student intends to say an electrical cord in English and does not know the term, he would call it 'a tube' or 'a wire with two plugs in both sides' (p.749). This 'current version' of language changes all the time but it can become a fossilized language when the learners do not have an opportunity to use it correctly.

Interlanguage seems to employ a different pattern from the target language. It does not follow the rules in the target language, such as the forming of verbs for past activities. Students might say 'buyed' to refer to 'bought' since they overgeneralize the forms of the regular verbs. Ellis (1994) supported this by saying that "interlanguages, like fully formed natural languages are rule governed, although the rules do not always correspond to the rules found in the target language" (p.462). The position of interlanguage can be said as in between learners' mother tongue and the target language being learned. It is supported by Selinker (1972), who defined the term 'interlanguage' to refer to the systematic knowledge of an L2 which is independent of both the students' L1 and the students' target language.

\section{FIVE CENTRAL PROCESSES}

The five psycholinguistic processes that shape interlanguage are hypothesised by Selinker (2007). They are (a) native language transfer in which learners transfer aspects of the first language (L1) to the second language (L2); (b) overgeneralization of target language rules, when learners use past tense (-ed verbs) for both regular and irregular ones; (c) transfer of training refers 
to difficulties to distinguish between pronouns 'he' and 'she'; (d) strategies of communication in which learners might not be aware or even leave out communicatively redundant grammatical items; and (e) strategies of learning which refers to when learners have adopted the strategy that all verbs are either transitive or intransitive, he may produce interlanguage forms such as 'I am feeling thirsty'.

\section{COMMUNICATION STRATEOIES}

Selinker (1972) proposes the notion of communication strategies to address certain classes of errors made by first/second language learners. This errors occur because of an incomplete learning of the target language. To be able to communicate in the target language, learners employ strategies. Meanwhile Tarone (1980) offers a concept of communication strategies as mutual efforts between two speakers who agree on a meaning in situations where the same meaning is not shared. The examples of strategies proposed by Tarone (as cited in Zhang Ya-ni 2007) include paraphrasing (approximation, word coinage, and circomlocution), conscious transfer (literal translation and language switch), appeal for assistance, mime, and avoidance (topic avoidance and message abandonment).

According to Dornyei and Scott (1997), the definition of communication strategies is a method of problem management in second language communication that help foreign/ second language learners arrange difficult meanings. They consider the communication strategies as problem solving techniques that cope with the language related problems of which the speakers were aware during the course of communication.
Here, the communicative strategies are considered as helpers for interlocutors that do not share certain language difficulties.

\section{RESEARCH TYPE}

This research belongs to an interlanguage study, to which the data will be collected from students' utterances when they are communicating in the target language (English). Selinker (1972) states that "the relevant data to be used in the study of interlanguage consisted of utterances produced by second-language learners when they were trying to communicate meaning in the target language" (p. 749).

\section{RESEARCH PARTICIPANTS}

The participants of this research were first year English Education Department students of a private university in Yogyakarta. They were assumed to have less English exposures compared to second and third year students of the same department. Four students with the highest score in the Listening and Speaking course were involved in this research. Those highest scored students were assumed to be able to converse and reveal various strategies compared to the lowest scored students who might stuck during the conversation and would not seem show any strategies. The participants consisted of three female students and one male student from four different classes. Pseudonyms were used to protect the privacy of the participants.

\section{DATA COLLECTION TECHNIQUES}

Firstly, based on the information received from the lecturers of the Speaking and Listening course with regard to the students with the 
highest score, who are assumed to have the ability to converse, the researcher contacted the participants to be interviewed using elicitation basedpicture conversation. This technique was used to elicit participants' utterances in English. The conversations were audio-recorded and transcribed. Member-checking was conducted to maintain the data reliability. No changes were suggested from the participants.

\section{FINDINGS}

\section{COMMUNICATION STRATEGIES USED IN A CONVERSATION.}

Message abandonment. The data show that when students did not find the conversation message which meets their prior knowledge, they would likely leave out the message. For example, Ani remarked "ya... stuff like that (laughing)," when she was going to say one term in the L2, yet she could not find the word. Another example was given by Iqbal. He stopped continuing what he was going to say since he did not know what to say. He said, "there are two floors so in front of the house there are small garden so it...". The last evidence about the first strategy was mentioned by Caca. She said, "I don't know how to describe it, but ...". The three utterances show that students would prefer to leave out some information when they did not know what to say in the L2 contexts.

Topic avoidance. When conversing in L2, students sometimes enjoy talking about topics that make them easy to convey in the L2 sentences. However, if they find difficultis to express their thoughts about one topic, they would skip the topic and go to the next topic. This was shown from Ani's utterances, "Err.... err... err... (long pause)... fireplace (saying it in her L1)... fireplace... (gesture: asking for a help). May be this is like Javanese design, you know like Joglo (Javanese traditional house) at the front." From this example, we see that Ani stopped discussing the fireplace in the picture since she could not find the term in L2; therefore, she moved on talking about the design of the house. Another remark was given by Iqbal who said, "Ah... the shape... the house is like triangle I mean the... err... the house is like (pause) the... the roof the roof its roof is triangle, big triangle in the front so at the back". He stopped talking about the shape of the house; instead, he mentioned the roof shape.

\section{CIRCUMLOCUTION}

In the conversation, when students did not know the L2 terms, they did not just stop talking. They employed a strategy named circumlocution, which refers to giving definitions or examples of the terms in L2. The evidence can be seen from the utterances of Ani, "You know a place where the families gather there with a fire in the snow season maybe ... winter". In the conversation, Ani did not know the L2 term for 'chimney'; instead, she defined the word as comprehensively as she could. Ani also mentioned "a house that has upstairs", to refer to a two-storey house. Not only Ani, the other student, Vada, also uttered, "we give them for a piece of bread" to mean 'to feed'. Vada also added, "It's like for make the room become warm with the with the... err... by we burn the wood like in a western...”. Vada was trying to say 'chimney'; however, she could not remember the term in $\mathrm{L} 2$. Thus, it came out using the circumlocution strategy to keep conversing. 
The circumlocution strategy was also employed by Iqbal to refer to 'fishpond'. He stated, "there is a pool, but not for swim". In addition, when Iqbal wanted to say 'chimney' in L2, it turned out to come out as "the place for smoke". From all the evidences of the circumlocution strategy, this can be said that foreign language learners might not actually not be aware of employing strategies in communication.

\section{APPROXIMATION}

The next strategy employed by the participants was approximation, which means finding the closest meaning of a word to refer to one thing. This was shown by Ani who used the term 'field' to refer to 'yard'. She realised that she commmited an error, yet she could not recall the term 'yard'. Instead, she came up with 'field' that she thought would have similar meaning to 'yard'. Another approximation strategy from Ani and Caca is when they wanted to say 'fishpond' in the L2, but they said 'fish pool'. In addition, Ani mentioned, "in the beside" to refer to 'side of the house'. This approximation happened since they are still in the process of learning.

\section{USE OF ALL-PURPOSE WORDS}

In the conversation, students also uttered several words to subtitute words they are lacking, such as 'stuff' and 'thing'. Ani used it in her utterance as follow: "Ya... stuff like that (laughing)". Here the word 'stuff' was actually subtituting words that she found it hard to remember. Another one was shown by Caca, "Chickens, cows, and like err.. what is that call it?". Instead of mentioning the other animal names, she easily filled the empty room in the utterance by saying 'what is that call it?".

\section{WORD COINAGE}

Due to the incomplete understanding of the L2, it might have caused learners' difficulties in expressing thoughts using L2. For example, students used the '-er' for comparative degree of each English adjective, which needed a certain rule when using it. This can be seen from the utterances, such as: 'more warm' for 'warmer'. Another example was shown by Caca who said 'fishes', since she understood that to form plural nouns, she needed to add 's' or 'es'. Thus, Caca still put 'es' in the noun. It can be said that the word coinage strategy is a strategy used to refer to a term in L2, in which the new term does not actually exist in the L2.

\section{LITERAL TRANSLATION}

In learning L2, many of L2 learners still use the literal translation. This happens since the knowledge of L1 most likely influences the L2 learners. This was reflected in the students' utterances, e.g., Ani's, "the important one of house is not about the shape or the design but who inside the house". Here "who inside the house' has the same grammatical structure as in the Indonesian language, the student's L1. Meanwhile the targeted form of the student's utterance is 'who is inside the house'. The sentence was lacking 'to be' because in the student's L1, 'to be' did not exist. Another example was given by Vada, "for my daily without I err... without I buy in the market or err..., " rather than "without buying". 


\section{CODE SWITCHING}

Code switching happens when students cannot find the bridge to convey their thoughts. This is the switch from the L2 (English) to L1 (Indonesian). In this research, code switching was found when one of the participants remarked "Err.... err... err... (long pause)... fireplace fireplace... (gesture: asking for a help). May be this is like Javanese design, you know like Joglo (Javanese traditional house) at the front". The words 'tungku' in the Indonesian context means fireplace. Another example was given by Ani, who mentioned, "(What is it, Sir?) err... I... the house has a fire what is it?. Err... what is it called?. 'fireplace', what's in English?". On another utterance, Ani also still switched to her L1, namely: "I imagine that this house has a big what.. big... field eee... is it field?... ya big field with err...."

Indirect appeal for help

The data show that in doing the English conversation the participants? actually frequently needed interlocutor's assistance to continue the conversation. This was indicated by their nonverbal (gestures) and verbal language. Ani said, "And... err... beautiful park, err... there is err... (what is pond?), err... (long pause)". Another evidence from Ani is: "Err.... err... err... (long pause)... fireplace fireplace... (gesture: whispering to ask the L2 term)". She was asking the term of those words in L2; however, she used gestures in conveying it.

\section{DIRECT APPEAL FOR HELP}

Other than the indirect appeal for help strategy, the oposite strategy named direct appeal for help also occurred in the data. This was shown from the utterances of the students, such as "(what is it called, Sir?) err... I... the house has a fire what is it?. Err... what is the name?. What is 'fireplace' in English, Sir?". The next example of the direct appeal for help was still from Ani's remark "You know a place where the families gather there with a fire in the snow season maybe ... winter. And... what else?". For the data, it was evident that the student was literally asking a question to get help from others.

\section{USE OF FILLERS}

It cannot be denied that in a conversation, both the interlocutor and the speaker will do some pauses to think for a while about what they want to say next. This strategy is usually aimed at extending the time to think of the coming up utterances. The data show that the participants of the research used this strategy as well. Caca stated, "The shape of the house hmm... wait... ". The word 'wait' here was the filler used by the speaker to think what to utter next. Ani also indicated the same strategy by saying "You know a place where the families gather there with a fire in the snow season maybe ... winter". In this utterance, the words 'you know' were used to extend the time for the speaker.

\section{SELF-REPAIR}

In this strategy, students would repeat what they have said in a corrected form without any influence from the interlocutor. This strategy also appeared in the data. Examples of the data from the conversation were expressions such as "I think that fish can relax ourselves when we saw... when we see the fish was err..." (Vada). In that utterance, Vada said 'when we saw...' however he then corrected himself by saying 'when we see'. 
Another example was from Iqbal, "I just want my house to be comfort... to comfort".

\section{SELF-REPETITION}

In self-repetition strategy, students tend to repeat the same words or phrases without any changes. This strategy was found in utterances like "I can plant and I can use it for my daily without I err... without I buy in the market (Ani). Another example was given by Vada, “... it control our... it control the.." and "like durian or mangos there that need a big ... a big... err... err... a huge space to... err... a huge space for the grow tree."

\section{CONCLUSION}

Students most likely employ a variety of strategies in their attempt to converse in their L2, which in this case is English. These strategies help them to maintain the conversation to take place although what they utter sometimes does not seem to have any grammatical process since the idea of communication strategies is to bridge the gap between the interlocutor and the speaker. The participants of the research also used several strategies in their conversation in L2. These strategies need to be acknowledged by English lecturers and school teachers to be promoted as one solution for students with low English proficiency.

\section{REFERENCES}

Dörnyei, Z., \& Scott, M. (1995). Communication strategies: An empirical analysis with retrospection. In J.S. Turley \& K. Lusby (Eds.) Selected papers from the proceedings of the 21st Annual Symposium of the Deseret Language and Linguistic
Society (p. 155-168). Provo, UT: Brigham Young University.

Dornyei, Z. \& Scott, M.L. (1997). Communication Strategies in a Second Language: Definitions and Taxonomies. Language Learning. 40, $173-210$

Ellis, R. (1994). The Study of Second Language Aquisition. USA: Oxford University Press.

Muho, A. \& Kurani, A (2011). Learning strategies in second language learning and teaching. Mediterranean Journal of Social Sciences. Vol 2(3). ISSN 2039-2117

Richards, J.C. et al. (1992). Longman dictionary of anguage teaching and applied linguistics. (Second edition) Harlow, Essex: Longman Group UK Limited

Selinker, L. (1972). Interlanguage. IRAL, 10, 209231.

Spromberg, Sarah. (2011). Communication Strategies Used by High School English Language Learners in Multilingual Classrooms. New York: Hunter College

Tarone, E. (1980). Communication strategies, foreigner talk and repair in interlanguage. Language Learning, 30, 417-431.

Tarone, E (2006). Interlanguage. Elsevier. 747-750 Ya-ni, Zhang. (2007). Communication strategies and foreign language learning. US-China Foreign Language 43-48/doi=10.1.1.87.2984

\section{Appendix 1}

Inventory of Communication Strategies with Descriptions, Examples (Based on Dörnyei and Scott, 1995a, 1995b)

\section{No Strategy Description Example}

1. Message abandonment Leaving a message unfinished because of some language difficulty 